\title{
Histological Remarks of the Uterus of Sympterygia acuta (Garman, 1877) and Sympterygia bonapartii (Müller \& Henle, 1841) (Chondrichthyes; Rajidae)
}

\author{
Características Histológicas del Útero de Sympterygia acuta (Garman, 1877) \\ y Sympterygia bonapartii (Müller \& Henle, 1841) (Chondrichthyes; Rajidae)
}

\author{
María Constanza Díaz-Andrade”,***; Andrea Lopez-Cazorla",**** \& Elena Juana Galíndez ${ }^{*}$
}

DÍAZ-ANDRADE, M. C.; LOPEZ-CAZORLA, A. \& GALÍNDEZ, E. J. Histological remarks of the uterus of Sympterygia acuta (Garman, 1877) and Sympterygia bonapartii (Müller \& Henle, 1841) (Chondrichthyes; Rajidae). Int. J. Morphol., 31(3):864-872, 2013.

SUMMARY: Chondrichthyes constitute a conserve and vulnerable clade of increasing importance. However, there is scarce knowledge about the morphological aspects of the reproduction, so that only one work exists about the structure of the gravid uterus of an oviparous species. The work presented here describes the morphological, histological and histochemical remarks of the uterus of two Rajids of the Sympterygia genus along the life cycle. Both species presented paired uteri that lead independently to a common urogenital sinus. The uteri of immature females are filiform, translucent and unspecialized tubes. When sexual development starts, all the genital system displays a transitional and progressive change. In all studied females, independently of the maturing stage, the same four layers were present all over the uterus: a mucosa, which comprises the lining epithelium and lamina propria, a submucosa, a muscular and a serosa. The major changes in the structure of the uterus along the life cycle occur in the mucosa. The uteri of mature, gravid and nongravid, females presents three distinguishable areas, cranial, medial and caudal, that vary both in the structure and histochemistry of the mucosa and in the thickness of the muscular layer. The results presented here are discussed in a physiological, adaptive and phylogenetic context.

KEY WORDS: Chondrichthyes; Rajidae; Uterus; Sympterygia.

\section{INTRODUCTION}

Chondrichthyans are the most ancient jawed group. They constitute a conserved clade, with some particular life history features, such as slow growth rate, low fertility and extensive period of gestation (Hoenig \& Gruber, 1990). These features make Chondrichthyes highly vulnerable to exploitation, so that the impact of fishing on chondrichthyan stocks around the world has become the focus of considerable international concern and debate.

Among cartilaginous fishes there is a wide variety of reproductive modes, ranging from oviparity to viviparity, depicting lecitotrophic and matrotrophic sources of nutrition (Musick \& Ellis, 2005; Wourms, 1981). Regardless the mode of reproduction, all living Chondrichthyans exhibit internal fertilization and the initial stages of embryogenesis occur within the female's genital tract.
The oviduct of Chondrichthyans is divided into several functional regions: ostium, anterior oviduct, oviductal gland, uterus and urogenital sinus. All species produce large megalecytic oocytes, filled with yolk supplies. Once ovulated, they pass from the peritoneal cavity to the ostium and are carried down the oviduct by ciliary action. Fertilization occurs at the anterior oviduct. The fertilized egg enters in the oviductal gland, where it is coated with the tertiary envelops (McMillan, 2007). Then, the encapsulated egg moves down through the uterus and stays there until complete embryonic development or oviposition (Hamlett \& Koob 1999; Stevens, 2002).

The development, structure and activity of the oviductal glands and uteri of cartilaginous fishes suffer important variations, according to the reproductive mode

\footnotetext{
* Laboratorio de Histología Animal, Departamento de Biología, Bioquímica y Farmacia, Universidad Nacional del Sur, Bahía Blanca, Argentina.

** Laboratorio de Zoología de Vertebrados, Departamento de Biología, Bioquímica y Farmacia, Universidad Nacional del Sur, Bahía Blanca, Argentina

*** CONICET, Argentina.

This work was supported by the SGCyT-UNS, PGI 24/B174.
} 
(McMillan). The main functions of the uteri are to house and protect the encapsulated eggs and embryos. Depending on the reproductive strategy, other functions can be added to these (Cateni et al., 2003).

Sympterygia acuta and S. bonapartii belong to the Rajidae family and, as such, are oviparous, producing chemically and structurally complex capsules to protect the fertilized egg. Even though these capsules are secreted by the oviductal glands (Galíndez et al., 2010a; Galíndez \& Estecondo, 2008; Koob \& Cox, 1988; Koob \& Hamlett, 1998; Lucifora \& García, 2004), the chemical reactions that result in the tanning and sclerotization of the capsule's wall, occur in the uterine lumen and are promoted by the conditions prevailing there (Koob \& Cox 1988; 1990). Despite this, the uterus of oviparous species has been considered primitive and unspecialized, regarding the physiological maintenance of the uterine environment and it has been studied in depth only in one oviparous species (Raja erinacea, Koob \& Hamlett). On this context, the aim of this study was to determine the morphological, histological and histochemical remarks of the uterus of $S$. acuta and $S$. bonapartii along the life cycle.

\section{MATERIAL AND METHOD}

A total of 23 females of $S$. acuta and 29 females of $S$. bonapartii were collected by line fishing in the inner and medium areas of the Bahia Blanca estuary (61 $30^{\circ}-62^{\circ} 30^{\prime}$ W, $\left.38^{\circ} 45^{\prime}-39^{\circ} 30^{\prime} \mathrm{S}\right)$. The total length and disc width of each specimen were measured at the nearest millimeter. The animals were terminated by blunt trauma to the cranium and immediately dissected. Once opened the ventral cavity, the sexual maturity stages were determined following the Stehmann (2002) criteria (Fig. 1). This standard technique, common on board, is based on the macroscopic aspect of the reproductive organs.

For light microscopy, tissue samples were fixed in Bouin's fixative in seawater, dehydrated through a graded series of alcohols and embedded in paraffin wax. Sections of 5-7 micrometers were stained with Masson's trichromic stain, hematoxylin-eosin, alcian blue technique at $2.5 \mathrm{pH}$ level $(\mathrm{AB} \mathrm{pH} 2.5)$ and periodic acid Schiff reaction (PAS). For scanning electron microscopy small pieces of different sections of the uterus were fixed in $2.5 \%$ glutaraldehyde in $0.05 \mathrm{M}$ sodium cacodylate buffer with $12 \%$ sucrose (Hyder et al., 1983), for 12 hours at $4{ }^{\circ} \mathrm{C}$ and post fixed in osmium tetroxide $1 \%$ in the same buffer for 90 minutes at $4{ }^{\circ} \mathrm{C}$. Samples were washed in the same buffer, then dehydrated in graded acetone, dried by critical point, coated by the ionsputtering method and examined in an Evo $40 \mathrm{XVP}$
(Cambridge, England) scanning electron microscope at 6 $\mathrm{KeV}$. Some samples were also embedded in Spurr's low density resin after fixation and semithin sections were stained with $1 \%$ toluidine blue and the acid fuchsine-azur II method.

\section{RESULTS}

Anatomy of the uterus. All the studied exemplars had paired uteri, dorsally located and running parallel to the spinal cord. They independently lead to a common urogenital sinus, of globular appearance, with thick muscular walls (Fig. 1).

In immature animals the uteri were filiform, translucent and flattened tubes, with a smooth inner surface (Fig. 1a). As animals mature, these organs became progressively wider and thicker (Fig. $1 \mathrm{~b}$ and c) and the inner surface acquired an irregular aspect, with longitudinal folds. The uteri of gravid females were highly distended due to the presence therein of egg cases. The organ walls were thin, translucent and profusely irrigated (Fig. $1 \mathrm{~d}$ ).

Microscopic morphology of the uterus. In all studied females, independently of the maturing stage, the same four layers were present all over the uterus: a mucosa, which comprises the lining epithelium and lamina propria, a submucosa of connective tissue, a muscular and a serosa.

The lining epithelium of immature uterus was simple columnar, formed by tall acidophilic cells, with euchromatic nucleus. This epithelium folded into low villi (Fig. 2, insert). Lamina propria and submucosa showed no particular features and were composed by dense connective tissue, with scarce vascularization. The muscular comprised two thin orthogonal sheets of smooth muscle, with the inner one in a circular disposition. The serosa was a thin layer of dense connective tissue lined by a simple cuboidal epithelium. No differences were observed in the uterine wall structure along the cranio-caudal axis.

In maturing females, the structure of the uterine wall was transitional, so that the features of the immature and mature animals coexisted. The mucosa showed low villi lined by simple to pseudostratified columnar epithelium, with scarce ciliated cells interspersed (Fig. 2). As females approached to sexual maturity, the lamina propria and the submucosa differentiated, being the former thin, of dense connective tissue and the latter thicker of loose and vascularized connective tissue. The muscular sheet was more developed and the orthogonal disposition remained. As in immature females, no differences were observed in the structure of the uterine wall along the longitudinal axis. 


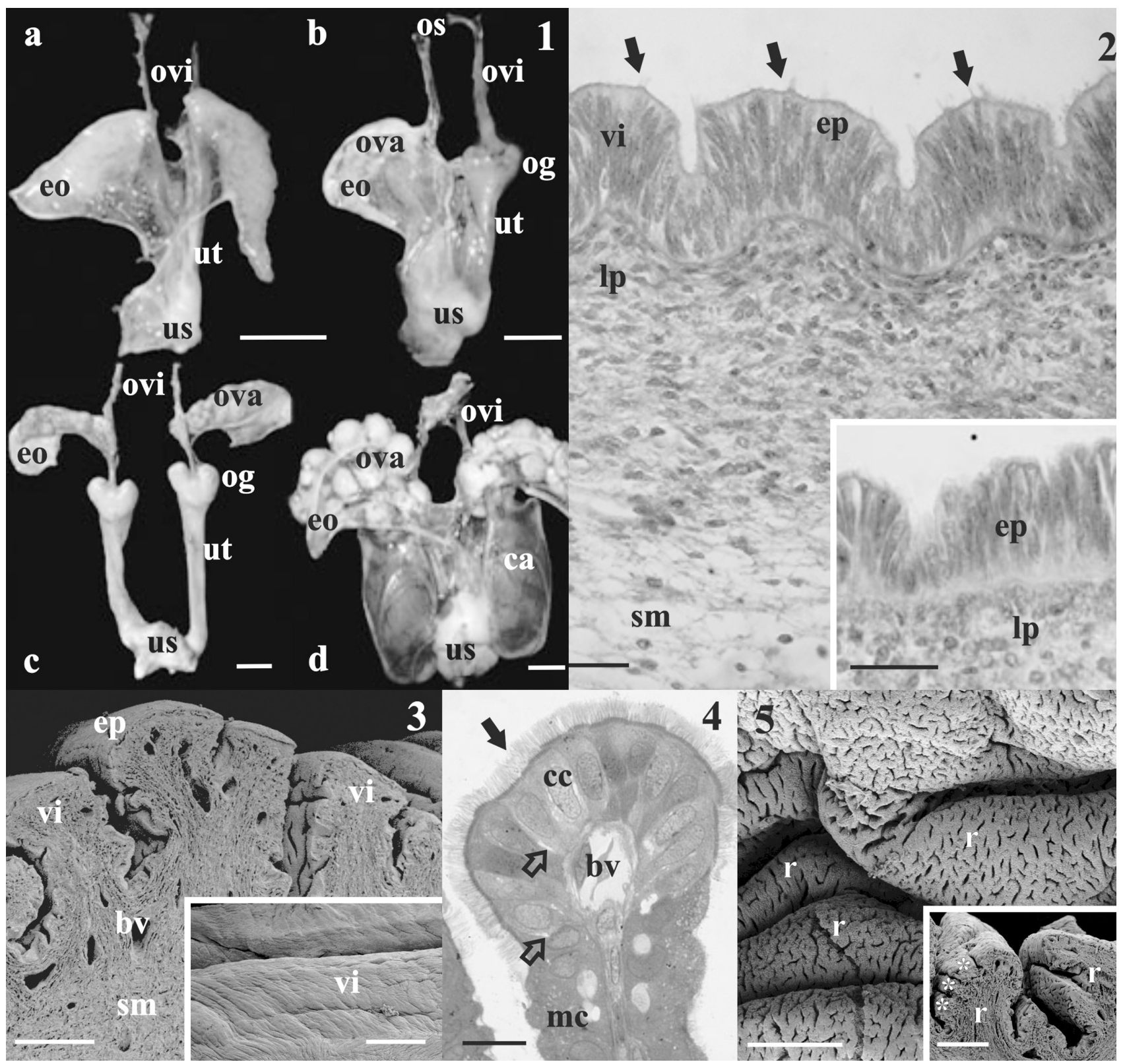

Fig. 1. General view of the female's reproductive organs in S. acuta (a and d) and S. bonapartii (b and c). a: Immature; b: Maturing; c: Mature non gravid; d: Gravid. ovi: oviduct; eo: epigonal organ; ut: uterus; us: urogenital sinus; os: ostium; ova: ovary; og: oviductal gland; ca: capsule. Scale bar: $20 \mathrm{~mm}$.

Fig. 2. High magnification of the uterine mucosa of an immature (insert) and maturing female of S. bonapartii. Arrow: cilia; ep: lining epithelium; lp: lamina propria; sm: submucosa; vi: villi. Masson's trichromic stain. Scale bar: $25 \mu \mathrm{m}$.

Fig. 3. SEM image of the transverse and longitudinal (insert) views of the cranial zone of the uterus in a mature non gravid female of $S$. bonapartii. bv: blood vessel; ep: lining epithelium; sm: submucosa; vi: villi. Scale bar: $200 \mu \mathrm{m}$.

Fig. 4. High magnification of a semithin section of the uterus cranial zone's mucosa in a mature non gravid S. bonapartii. Black arrow: cilia; bv: blood vessel; cc: ciliated cells; empty arrow: intercellular spaces; mc: mucous cells. Toluidine blue stain. Scale bar: $150 \mu \mathrm{m}$. Fig. 5. SEM image of the longitudinal and transverse (insert) views of the medial zone of the uterus in a mature non gravid female of $S$. bonapartii. r: ridges; asterisk: villi. Scale bar: $250 \mu \mathrm{m}$.

The uteri of mature, but non-gravid females varied from cranial to caudal, both in the structure of the mucosa and in the thickness of the muscular layer, so that three areas were distinguishable: cranial, medial and caudal (Figs. 3 to 10). 
Cranial zone. In this region, the mucosa folded in small and simple villi (Fig. 3). The lining epithelium was simple columnar to pseudostratified, with two cell types: tall ciliated acidophilic cells, with centrally euchromatic and peripherally heterochromatic nucleus and lower, acidophilic, non-ciliated cells, with euchromatic nucleus. Ciliated cells were abundant and located at the apex and upper margins of the villi (Fig. 4). They exhibited some vacuoles in their cytoplasm and intercellular spaces. On the other hand, mucous cells were restricted to the side margins, forming simple or ramified small tubular glands. These cells had a rounded apical surface and their cytoplasm was plenty of mucous vesicles, which accrete in that surface (Fig. 4). This mucous substance was secreted by exocytosis and usually deposited as a thick border on the outer margin of the cell. The vesicles reacted positively to the PAS stain and a small number of them also reacted to the $\mathrm{AB} \mathrm{pH}$ 2.5. Beneath the lining epithelium there was a thin lamina propria of dense connective tissue and small blood vessels (Fig. 4). Submucosa was thick, of loose connective tissue and highly vascularized. The muscular was composed of two orthogonal layers of smooth muscular cells disposed in compact bundles and innervated by autonomic ganglia. The serosa was typical (Fig. 9).

Medial zone. As in the cranial zone, the mucosa folded in villi, while the mucosa and submucosa folded together to form major ridges (Fig. 5 and 10). The lining epithelium showed the same cell types mentioned above, even though ciliated cells were less abundant than in the cranial zone and were located only in the apex of the villi. In this zone it was common the presence of apoptotic ciliated cells. On the other hand, mucous cells were more abundant and arranged in the remaining area (Fig. 6). The lamina propria and submucosa displayed similar features to the previously described. The muscular was more prominent and the serosa showed no changes (Fig. 10).

Caudal zone. As in the medial zone, the mucosa and submucosa folded in villi and ridges (Fig. 7, 8 and 10). The villi that were located at the apex of the ridges were upholstered by cubic mucous cells, whereas the lining epithelium of those present between creases was formed almost exclusively by columnar mucous cells, with occasional ciliated cells (Fig. 8). Lamina propria and submucosa showed no changes and the muscular was considerably thicker than in the other zones. The serosa was typical (Fig. 10).

At the level of the juncture between the uterus and the urogenital sinus, the lining epithelium becomes stratified cuboidal, with some PAS (+) cells (Fig. 11). Beneath this layer there was a thick stratum of dense connective tissue with scarce vascularization and a prominent muscular, composed by two orthogonal sheets. The serosa showed no changes.

Gravid females had forming egg cases, simultaneously in both uteri. In all cases, the capsule assembly started from the rear end, so that posterior horns and projections were fully developed (Fig. 12). The newly formed capsule wall was thin, limp and white, while the area of the case that was within the uterus was thicker, harder and iridescent olive colored (Fig. 12).

The uteri of gravid females (Fig. 13) showed the same morphological features than non-gravid animals, along the longitudinal axis. Since this organ contained the capsule, the entire uterine wall appeared thinner. The ridges became shallower as result of the distention, so that only the villi remained. On the other hand, vascularization of the lamina propria and submucosa was more developed than in nongravid females.

\section{DISCUSSION}

The oviducts of Chondrichthyes are derived from the Müellerian ducts and demonstrate many homologies to the oviducts of other Vertebrates (McMillan). The anatomical disposition of the uteri of Sympterygia acuta and $S$. bonapartii is consistent with that seen in all studied Chondrichthyes (Díaz-Andrade et al., 2011; Galíndez et al., 2010a; Hamlett \& Hysell, 1998; Koob \& Hamlett).

The undeveloped and unspecialized aspect of the uterus in immature females of both species agrees with its developmental stage. When sexual development starts, all the genital system displays a transitional and progressive change, where the features of immature and mature uteri coexist. On the other hand, the morphological specializations of the uterus of sexually mature females in the studied species would be adaptations to the functional activities associated with the process of formation, modification and movement of the egg capsule (Galíndez et al., 2010a; Galíndez \& Estecondo; Koob \& Cox, 1993).

Sympterygia acuta and S. bonapartii are single oviparous species, producing one capsule in each oviductal gland simultaneously (Díaz-Andrade, 2011). In general, the formation of this capsule begins before ovulation, as it does in other chondrichthyan species (Hobson, 1930; Metten, 1939). The changes along the cranio-caudal axis, either in the complexity of the folds, the amount of each cell type and in the disposition and thickness of the muscular layer, would be correlated with the passage of the capsule inside the uterus. 


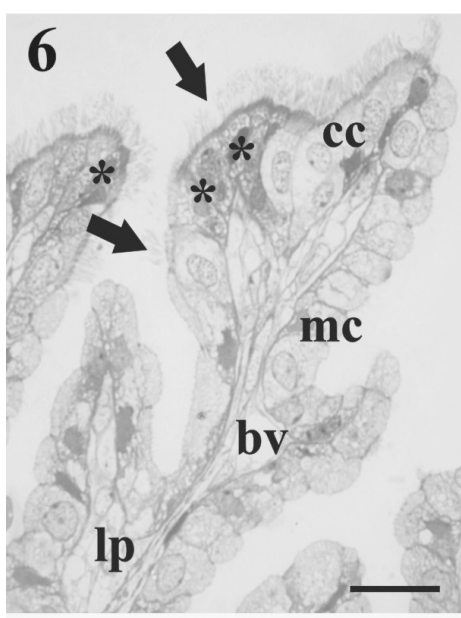

9

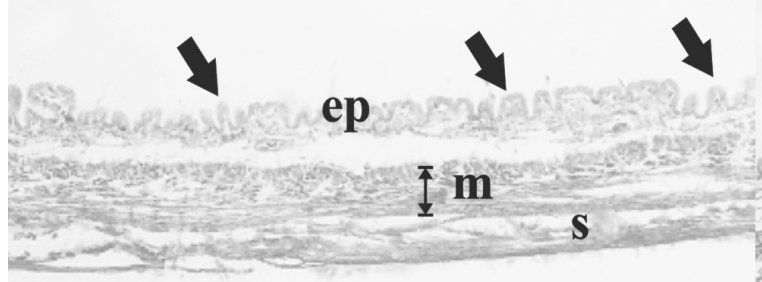

10

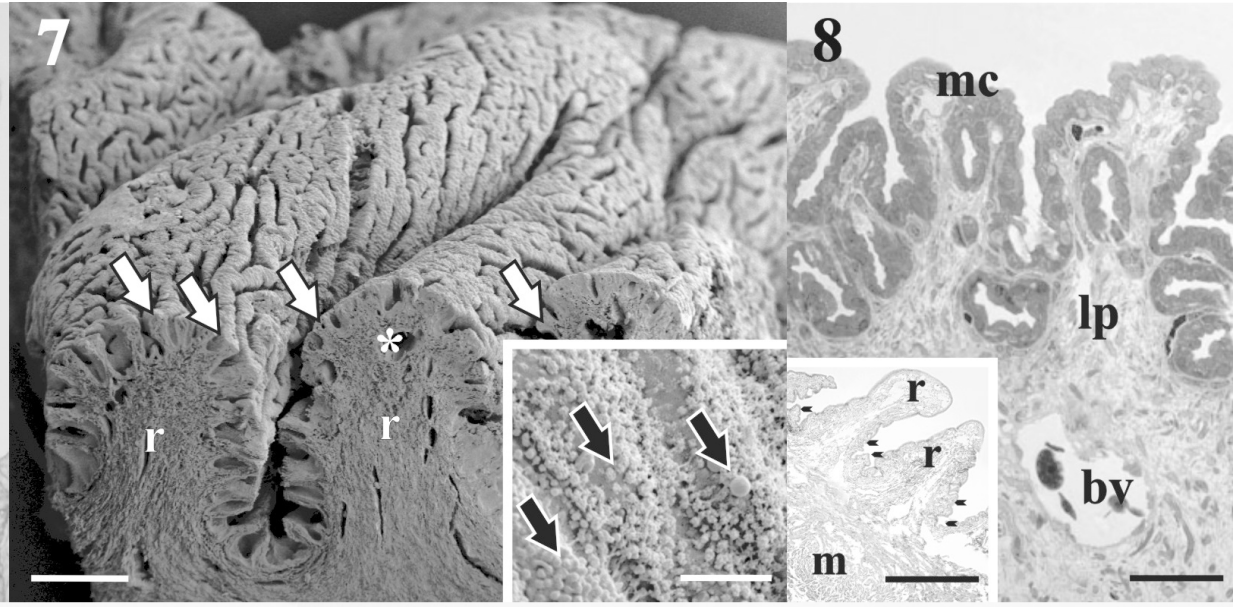


Fig. 9. General view of the cranial uterine wall of a mature non gravid S. acuta. Arrow: villi; ep: lining epithelium; m: muscular; s: serosa. Masson's trichromic stain. Scale bar: $200 \mu \mathrm{m}$.

Fig. 10. General view of the transition between the medial (ME) and caudal (CA) zones of the uterus of a mature non gravid female of $S$. acuta. Arrow: villi; bv: blood vessel; ep: lining epithelium; m: muscular; r: ridges; sm: submucosa; s: serosa. Masson's trichromic stain. Scale bar: $250 \mu \mathrm{m}$.

Fig. 11. High magnification of the urogenital sinus mucosa, at the level of the junction between it and the uterus in $S$. acuta. ep: lining epithelium; lp: lamina propria. PAS reaction. Scale bar: $100 \mu \mathrm{m}$.

Fig. 12. Macroscopical view of the newly formed capsule inside the uterus of $S$. acuta. The uterine wall was cut longitudinally to show the capsule's discoloration in thearea adjacent to the oviductal gland. Black arrow: capsule's posterior horns; c: capsule; og: oviductal gland; uw: uterine wall. Scale bar: $15 \mathrm{~mm}$.

Fig. 13. High magnification of the uterus wall in a gravid female of S. acuta. bv: blood vessel; ep: lining epithelium; lp: lamina propria; sm: submucosa. Masson's trichromic stain. Scale bar: $100 \mu \mathrm{m}$.

Although the extrusion force generated during the secretion process of the components of the capsule in the oviductal gland promotes its displacement within the gland (Knight \& Feng, 1996), it does not appear to be enough to drive the capsule inside the uterus. The orthogonal disposition of the muscular sheet observed in the uteri of $S$. acuta and $S$. bonapartii is typical of hollow organs that perform movements of peristaltic type. Although this muscular arrangement has also been reported in $R$. erinacea (Koob \& Hamlett), in that case the disposition was opposite to that observed in the present study. However, this uniqueness does not seem to have any functional implications. Moreover, muscle contraction on the anterior portion of the uterus would put an excessive pressure on the newly formed capsule, so it is likely that the movement in that zone is carried out by ciliary action. This hypothesis is supported mainly by two facts: on one hand, ciliary cells are progressively replaced by mucous cells along the longitudinal axis, as evidenced by the large number of apoptotic images present at the medial zone. On the other hand, the abundance of ciliated cells is also inversely proportional to the thickness of the muscularis along the cranio-caudal axis, so that in the caudal region of the uterus the movement of the tough sclerotized capsule might be carried out by the action of the muscle fibers and facilitated by the secretion of the mucous cells. This adaptations are also consistent with the fact that the newly formed capsule that enters in the uterus is flexible, so it seems to be unnecessary the presence of highly developed folds to allow a high distention. Moreover, Koob et al. (1981) and Koob \& Hamlett have shown, in $R$. erinacea, that this region of the uterus may alter its ability to strain, as the female is pregnant or not, due to a change in the characteristics of the connective tissue matrix in response to certain hormonal stimuli.

The histochemical reaction observed in the secretory cells of the uterine epithelium in S. acuta and S. bonapartii indicates the presence of neutral glucoproteins and both, sulpho and sialomucins. Presumably, these secretions may play a role as a lubricant, which facilitates the displacement of the capsule along the uterus. Koob \& Hamlett observed the presence of mucopolysaccharides in $R$. erinacea and stated that "clearly the uterine epithelium in this oviparous species synthesizes and secretes material that is likely involved in capsule formation and/or processing in the uterus". Beyond that, the exact nature of these secretions and their physiologic role in oviparous Chondrichthyes remain still unknown.

As in all studied Chondrichthyes, each uterus independently joins a common urogenital sinus and it is common to find a sphincter-like muscular structure at the ends of the uterus of viviparous species (Galíndez et al., 2010b; Hamlett \& Hysell; McMillan; Storrie et al., 2009). However, it seems to be no such structure limiting the uterine lumen in oviparous species, like $S$. acuta, S. bonapartii and $R$. asterias (Koob \& Hamlett). It is likely that the widening of the muscular wall at the level of the junction of the uterus with the urogenital sinus fulfils a similar role, especially considering the absence of fetal movements. On the other hand, the urogenital sinus of $S$. acuta and S. bonapartii enlarges as sexual development progresses, as it does in other species (Hamlett \& Koob; Steven, 1934). In oviparous species, this is probably due to the fact that they usually house the case in the urogenital sinus for several hours before oviposition (Hamlett \& Koob).

The capsule provides a convenient environment for the embryonic development and protects the embryo from predation, mechanical injury, fouling and infection throughout an extended period of development. Its wall is extremely tough and resistant to chemical and enzymatic attack though freely permeable to small molecules and ions (Galíndez et al., 2010a; Galíndez \& Estecondo; Koob \& Cox, 1988; Oddone et al., 2006). This envelope is resistant to bursting and is filled with a viscous jelly-like material that functions as an efficient shock absorber (Koob \& Strauss, 1998). The capsule wall is a composite material constructed largely of collagen fibrils (Knight \& Feng, 1992; Koob \& 
Cox, 1988; Smith et al., 2004; Oddone et al.). The final sclerotization and tanning of the capsule proceeds and is completed in the uterine lumen. As in $S$. acuta and $S$. bonapartii, in $R$. erinacea the egg capsule is white when it leaves the oviductal gland. Koob $(1987 ; 1991)$ and Koob \& Cox $(1988 ; 1990 ; 1993)$ have found in $R$. erinacea, that the capsular stabilization may occur by capsule enzymes and in presence of $\mathrm{O}_{2}$. The extensive vascularization observed in the uterine chorion and submucosa in pregnant females of $S$. acuta and S. bonapartii, suggests that the needed oxygen is supplied via maternal circulation, as in R. erinacea (Koob \& Hamlett). Similar observations on the uterine vascular system in viviparous elasmobranches (Galíndez et al., 2010b, Hamlett \& Koob) suggest that one basic function of the uteri of these females is the supply of oxygen to the uterine lumen.

The information here presented, indicates that the uterus of S. acuta and S. bonapartii fits structurally and physiologically, not only to allow the passage of the encapsulated egg, but also promotes the reactions that give the capsule its characteristic features. However, many of these modifications are similar to those present in viviparous species, so that the capacity of the uterus to satisfy the physiological demands of each reproductive mode would rely on a few basic mechanisms, such as structural modifications that allow passage of the egg or embryo, oxygen supply to the uterine lumen and biosynthesis, secretion and/or modification of structural or nutritious materials (Koob \& Hamlett; Stevens; Galíndez et al., 2010b). These facts would be consistent with current theories, which refer to oviparity as the derivative mode and viviparity as the plesiomorphic character (Dulvy \& Reynolds, 1997, Long et al., 2009).

As mentioned above, cartilaginous fishes constitute a highly adapted and diverse group, with regards to its reproduction. However, the structure of its genital system constitutes a morphological model that has been conserved throughout its evolutionary radiation. This is probably due to the fact that it constitutes a pattern that is easily adaptable to different reproductive strategies, providing a plasticity that has led Chondrichthyes to be worthy competitors of the prolific bony fishes.

\section{ACKNOWLEDGMENTS}

We thank the Prefectura Naval Bahía Blanca for their help in samplings.

DÍAZ-ANDRADE, M. C.; LOPEZ-CAZORLA, A. \& GALÍNDEZ, E. J. Características histológicas del útero de Sympterygia acuta (Garman, 1877) y Sympterygia bonapartii (Müller \& Henle, 1841) (Chondrichthyes; Rajidae). Int. J. Morphol., 31(3):864-872, 2013.

RESUMEN: Los condrictios constituyen un clado sumamente conservado y vulnerable a la explotación, que ha cobrado una importancia creciente en los últimos años. Sin embargo, existe poca información sobre los aspectos morfológicos relacionados con la reproducción; tanto así, que la estructura del útero en hembras grávidas sólo ha sido estudiada en profundidad en una especie ovípara. El presente trabajo describe las características morfológicas, histológicas e histoquímicas del útero de dos especies de Rájidos del género Sympterygia a lo largo del ciclo de vida. Ambas especies presentan úteros pares que desembocan independientemente en un seno urogenital común. El útero de las hembras inmaduras es filiforme, translúcido y poco especializado. Cuando se inicia el desarrollo sexual, todo el sistema genital exhibe un cambio direccional y progresivo. En todas las hembras estudiadas, independientemente del grado de madurez, se encontraron las mismas cuatro túnicas a lo largo del útero: una mucosa, compuesta por un epitelio de revestimiento y un corion, una submucosa, una muscular y una serosa. Los cambios mayores en la estructura del útero a lo largo del ciclo de vida ocurren a nivel de la mucosa. En el útero de hembras maduras, grávidas o no grávidas, se pueden reconocer tres regiones claramente diferenciables, craneal, media y caudal, que varían tanto en la estructura como en la afinidad histoquímica de la mucosa, así como en el grosor de la túnica muscular. Los resultados del presente trabajo se discuten en un contexto fisiológico, filogenético y adaptativo.

PALABRAS CLAVE: Chondrichthyes; Rajidae; Útero; Sympterygia.

\section{REFERENCES}

Cateni, C.; Paulesu, L.; Bigliardi, E. \& Hamlett, W. C. The interleukin I (Il-1) system in the uteroplacental complex of a cartilaginous fish, the smoothound shark Mustelus canis. Reprod. Biol. Endocrinol., 1:25, 2003.
Díaz-Andrade, M. C. Morfofisiología de la biología reproductiva de las especies del género Sympterygia que habitan el estuario de Bahía Blanca. Tesis doctoral, Universidad Nacional del Sur, Bahía Blanca, Argentina, 2011. p.281. 
DÍAZ-ANDRADE, M. C.; LOPEZ-CAZORLA, A. \& GALÍNDEZ, E. J. Histological remarks of the uterus of Sympterygia acuta (Garman, 1877) and Sympterygia bonapartii (Müller \& Henle, 1841) (Chondrichthyes; Rajidae). Int. J. Morphol., 31(3):864-872, 2013.

Díaz-Andrade, M. C.; Galíndez, E.; López-Cazorla, A. \& Estecondo, S. Ovarian folliculogenesis in the smallnose fanskate Sympterygia bonapartii (Müller \& Henle, 1841) (Chondrichthyes, Rajidae). Int. J. Morphol., 29(1):17481, 2011.

Dulvy, N. K. \& Reynolds, J. D. Evolutionary transitions among egg-laying, live-bearing and maternal inputs in sharks and rays. Proc. Biol. Sci., 264(1386):1309-15, 1997.

Galíndez, E. J.; Díaz-Andrade, M. C.; Avaca, M. S. \& Estecondo, S. Morphological study of the oviductal gland in the smallnose fanskate Sympterygia bonapartii (Müller \& Henle, 1841) (Chondrichthyes, Rajidae). Braz. J. Biol., 70(2):325-33, 2010a.

Galíndez, E.; Díaz-Andrade, M. C.; Moya, A. C.\& Estecondo, S. Morphological changes in the pregnant uterus of the smooth hound dogfish Mustelus schmitti Springer, 1939 (Gatuzo) (Condrichthyes, Triakidae). Microscopic study and phylogenetic reproductive implications. Int. J. Morphol., 28(4):1003-10, 2010 b.

Galíndez, E. J. \& Estecondo, S. Histological remarks of the oviduct and the oviductal gland of Sympterygia acuta Garmann, 1877. Braz. J. Biol., 68(2):359-65, 2008.

Hamlett, W. C. \& Hysell, M. K. Uterine specializations in elasmobranch. J. Exp. Zool., 282(4-5):438-59, 1998.

Hamlett, W. \& Koob, T. Female reproductive system. In: Hamlett, W. (Ed.). Sharks, Skates and Rays. The biology of Elasmobranch Fishes. Baltimore, The John Hopkins University Press, 1999. pp.398-443.

Hobson, A. D. A note on the formation of the egg-case of the skate. J. Mar. Biol. Assoc. U.K., 16(2):577-81, 1930.

Hoenig, J. \& Gruber, S. Life-story patterns in the elasmobranchs: implications for fisheries management. In: Pratt, H.; Gruber, S. \& Taniuchi, T. (Eds.). Elasmobranchs as living resources: advances in the biology, ecology, systematic, and the status of the fisheries. NOAA Tech. Rep. NMFS, 90. Seattle, NOAA/ National Marine Fisheries Service, 1990. pp.1-16.

Hyder, S. L.; Cayer, M. L. \& Pettey, C. L. Cell types in peripheral blood of the nurse shark: an approach to structure and function. Tissue Cell, 15(3):437-55, 1983.

Knight, D. P.; Feng, D. \& Stewart, M. Structure and function of the Selachian egg case. Biol. Rev., 71:81-111, 1996.
Koob, T. J. Effects of oxidation and reduction on the spectral properties of the egg capsules of Raja erinacea Mitchill. J. Exp. Mar. Biol. Ecol., 113(2):155-66, 1987.

Koob, T. J. Deposition and binding of calcium and magnesium in egg capsules of Raja erinacea Mitchill during formation and tanning in utero. Copeia, 1991(2):339-47, 1991.

Koob, T. J. \& Cox, D. L. Egg capsule catechol oxidase from the little skate, Raja erinacea Mitchill, 1825. Biol. Bull., 175(2):202-11, 1988.

Koob, T. J. \& Cox, D. L. Introduction and oxidation of catechols during the formation of the skate (Raja erinacea) egg capsule. J. Mar. Biol. Assoc. U.K., 70:395411, 1990.

Koob, T. J. \& Cox, D. L. Stabilization and sclerotization of Raja erinacea egg capsule proteins. Environ. Biol. Fishes, 38:151-7, 1993.

Koob, T. J. \& Hamlett, W. C. Microscopic structure of the gravid uterus in the little skate, Raja erinacea. J. Exp. Zool., 282:421-37, 1998.

Koob, T. J.; Laffan, J. L. \& Callard, I.P. Egg-oviduct size relationships in Raja erinacea. Bull. Mt. Desert. Isl. Biol. Lab., 21:46-8, 1981.

Koob, T. J. \& Straus, J. W. On the role of egg jelly in Raja erinacea. Bull. Mt. Desert. Isl. Biol. Lab., 37:117-9, 1998.

Knight, D. P. \& Feng, D. Formation of the dogfish egg capsule: A coextruded, multilayer laminate. $J$. Biomimetics, 1:151-75, 1992.

Long, J. A.; Trinajstic, K. \& Johanson, Z. Devonian arthrodire embryos and the origin of internal fertilization in vertebrates. Nature, 457(7233):1124-7, 2009.

Lucifora, L. O. \& García, V. B. Gastropod predation on egg cases of skates (Chondrichthyes, Rajidae) in the Southwestern Atlantic: quantification and life history implications. Mar. Biol. (Berlin), 145(5):917-22, 2004.

McMillan, D. Fish histology. Female reproductive system. Dordrecht, Springer, 2007.

Metten, H. Studies on the reproduction of the dogfish. Philos. Trans. R. Soc. London B, 230(569):217-38, 1939. 
DÍAZ-ANDRADE, M. C.; LOPEZ-CAZORLA, A. \& GALÍNDEZ, E. J. Histological remarks of the uterus of Sympterygia acuta (Garman, 1877) and Sympterygia bonapartii (Müller \& Henle, 1841) (Chondrichthyes; Rajidae). Int. J. Morphol., 31(3):864-872, 2013.

Musick, J. A. \& Ellis, J. Reproductive evolution of Chondrichthyans. In: Hamlett, W. C. \& Jamieson, B. G. M. (Eds.). Reproductive biology and phylogeny. Vol. 3. Enfield, Science publishers INC, 2005. pp.45-79.

Oddone, M. C.; Mesa, A. \& Ferreira de Amorim, A. The egg capsule of Rioraja agassizi (Müller \& Henle) (Elasmobranchii, Rajidae), endemic to the SW Atlantic. Pan Am. J. Aquat. Sci., 1(2):43-8, 2006.

Smith, R. M.; Walker, T. I. \& Hamlett, W. C. Microscopic organization of the oviducal gland of the holocephalan elephant fish, Callorhynchus millii. Mar. Freshwater Res., 55(2):155-64, 2004.

Stehmann, M. F. W. Proposal of a maturity stages scale for oviparous and viviparous cartilaginous fishes (Pisces, Chondrichthyes). Arch. Fish. Mar. Res., 50:23-48, 2002.

Steven, G. A. Observations on the growth of the claspers and cloaca in Raia clavata Linnaeus. J. Mar. Biol. Assoc. U.K., 19:887-99, 1934.

Stevens, B. Uterine and oviductal mechanisms for gestation in the common sawshark, Pristiophorus cirratus. Bachelor of Science (Honors) Thesis, University of Melbourne, Melbourne, Australia, 2002.

Storrie, M. T.; Walker, T. I.; Laurenson, L. J. \& Hamlett, W. C. Gestational morphogenesis of the uterine epithelium of the gummy shark (Mustelus antarcticus). J. Morphol., 270(3):319-36, 2009.

Wourms, J. P. Viviparity: The maternal-fetal relationship in fishes. Amer. Zool., 21(2):473-515, 1981.
Correspondence to:

Dra. María Constanza Díaz Andrade

Departamento de Biología, Bioquímica y Farmacia

Universidad Nacional del Sur

San Juan 670, 8000, Bahía Blanca

ARGENTINA

Phone: +54(0291)4595100 (int. 2436)

Fax: +54(0291)4595130.

Email: mcandrade@criba.edu.ar

Received: 11-03-2013

Accepted: 19-05-2013 